\title{
The Effect of Macro-Micro Fertilizer Ratio on leaf Brassica oleracea Variety Green Dwarf Curly with Floating Hydroponic System
}

\author{
Yati Setiati ${ }^{1}$, Maulida Ayu Lestari ${ }^{2}$, Budy Frasetya ${ }^{3}$, M. Subandi ${ }^{4}$ \\ \{yatisetiati@uinsgd.ac.id ${ }^{1}$, maulidaaayu@gmail.com² ${ }^{2}$,budyftq1682@gmail.com ${ }^{3}$, mhdsubandi@yahoo.co.id ${ }^{4}$ \} \\ Faculty of Science and Technology, UIN Sunan Gunung Djati Bandung ${ }^{1}$
}

\begin{abstract}
Floating hydroponic system is simple hydroponic system, because roots can absorb nutrient element the sub merged direct root nutrients solution. The ratio of macro-micro fertilizer to hydroponic can effect leaf growth. The aimed of this research was to know effect of ratio macro-micro fertilizer on Brassica oleracea leaf. The research was conducted at Jatinangor subdistrict from August to October 2018 used Randomized Complete Design with nine replications. The study was conducted to examine various macro (NPK, $\mathrm{CaSO}_{4}$, $\mathrm{MgSO}_{4}, \mathrm{~K}_{2} \mathrm{SO}_{4}$ and Soluble Micro Mix fertilizer ratio i.e : A (AB Mix) as a control, B (1250:312.1: 583.68 $: 250: 50)$, C (1250:312.1 : $583.68: 250: 70)$, D (1250:312.1: $583.68: 250: 90)$, E (1250:312,1: 583,68 $: 250: 110), \mathrm{F}(1562,5: 350,12: 730,1: 324,78: 50), \mathrm{G}(1562.5: 350.12: 730.1: 324.78: 70), \mathrm{H}(1562.5$ : $350.12: 730.1: 324.78: 90)$ dan I $(1562.5: 350.12: 730.1: 324.78: 110)$. The results showed that there was an effect of macro and micro fertilizer ratio on number of leaf, number of chorophyll, and leaf area Brassica olerace. The ratio of pupuk NPK $(1562,5): \mathrm{CaSO}_{4}(350,12): \mathrm{MgSO}_{4}(730,1): \mathrm{K}_{2} \mathrm{SO}_{4}(324,78)$ : 90 Soluble macro mix was recommended as an alternative to substitution $\mathrm{AB}$ mix fertilizer.
\end{abstract}

Keywords: Brassica oleracea, Hydroponic, macro-micro fertilizer ratio

\section{Introduction}

As time goes by, land that used to be agricultural land, began to be displaced and replaced by many industrial sectors. Moreover, in the urban area, the lack of land makes people difficult to cultivate crops. With the development of technology in the field of agriculture increasingly rapidly, can be utilized and disseminated one of them is hydroponic technology [1]. Hydroponic can be utilized and disseminated, one of them is hydroponic technology. One of the hydroponics system is floating hydroponic system. This system includes a simple system compared to other systems. It is said to be simple because it is easy to make, with tools and materials that are easy to obtain, not require a lot of costs, and not have to have special abilities to make this[2]. In this system, plants are planted over a nutrient solution that is accommodated in a tub[3].

One of the important things in hydroponic is nutrients. Because nutrition on hydroponics is a source of nutrients needed by plants[4]. Nutrition with a total N-200 ppm and $250 \mathrm{ppm}$ is a nutrient that is able to meet the needs of leaf vegetables [5]. Obtained formulations for the use of NPK of $1250 \mathrm{~g}$ with a total N-200 ppm and $1562.5 \mathrm{~g}$ with a total N-250 ppm. The addition of $\mathrm{CaSO}_{4}, \mathrm{MgSO}_{4}$, and $\mathrm{K}_{2} \mathrm{SO}_{4}$ is also important. This is because the function of these elements which greatly supports the growth of plants, especially leafy vegetable plants[6].

Therefore, thepresent experiment was conducted to observe the give macro-micro fertilizer ratio of leaf Brassica oleracea grown hydroponically.

\section{Methode}

A green house trial at Green House research station of Universitas Padjadjaran at $734 \mathrm{~m}$ above sea level was carried out from August to October 2018. Material used were Brassica oleracea seed varietas Green Dwarf Curly, AB MIX fertilizer, macro-micro fertilizer ratio of 
chemical compound macro fertilizer ( $\mathrm{NPK}, \mathrm{MgSO}_{4}, \mathrm{CaSO}_{4}$, and $\mathrm{K}_{2} \mathrm{SO}_{4}$ ), Soluble micro mix , Plastic tub $30 \mathrm{~cm} \times 25 \mathrm{~cm} \times 10 \mathrm{~cm}$, styrofoam, netpot, rockwool, tray seed, aerator, T pipe, EC meter, $\mathrm{pH}$-meter.

The experiment used completely randomized design with nine treatment. The treatment were i.e : A (AB Mix) as a control, B (1250:312.1: $583.68: 250: 50)$, C (1250:312.1: $583.68: 250: 70)$, D (1250: $312.1: 583.68: 250: 90)$, E (1250:312,1:583,68: $250: 110), \mathrm{F}(1562,5: 350,12: 730,1: 324,78: 50), \mathrm{G}(1562.5: 350.12$ $: 730.1: 324.78: 70)$, H (1562.5: $350.12: 730.1: 324.78: 90)$ dan I (1562.5: $350.12: 730.1: 324.78: 110)$.

Kale seedlings 14 days were planted on netpot. Continue and periodic fertigation with floating raft hidroponic system (Figure 1).

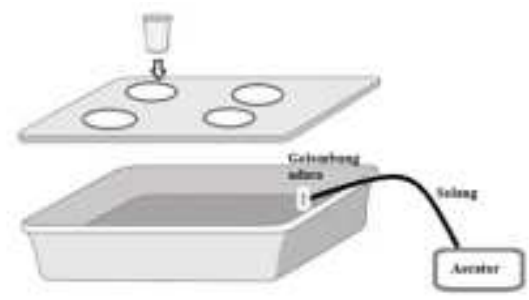

Figure 1. Floating raft Instalation

\section{Result and Discussion Number of leaf}

After the research, the results showed a variety of Kale plant growth, especially in the leaves of the Kale plant. As we can see in the diagram, number of Kale leaf in A treatment which is given $\mathrm{AB}$ Mix as the nutrient, showed the best growth. It means that $\mathrm{AB}$ Mix has the best nutrition formulation that is complete and sufficient for plant needs. Beside that, $\mathrm{H}$ treatment gives the second best of the research. In $\mathrm{H}$ treatment, the researcher given a modified nutrition formulation that contains NPK : $\mathrm{CaSO}_{4}: \mathrm{MgSO}_{4}: \mathrm{K}_{2} \mathrm{SO}_{4}:$ Micro in the amount of $1562,5: 350,12: 730,1: 324,78: 90(\mathrm{~g})$ (Figure 2). It showed that modified nutrition formulation, can be also quite effective as a hydroponic nutrient. The number of leaves is strongly influenced by the element of nitrogen $(\mathrm{N})$ where the function of element nitrogen $(\mathrm{N})$ is to accelerate plant growth associated with leaves, number of branches, and number of tillers so that nitrogen $(\mathrm{N})$ is needed for growth and propagation of leaves. Besides that, micro elements also play a role in plant growth[7]. There are elements of $\mathrm{Mn}$ and $\mathrm{Cu}$ in micro soluble micro mix, which function as enzyme activators so that these enzymes can stimulate cell division and formation of shoots in the stem so that more segments for leaf growth [8]. 


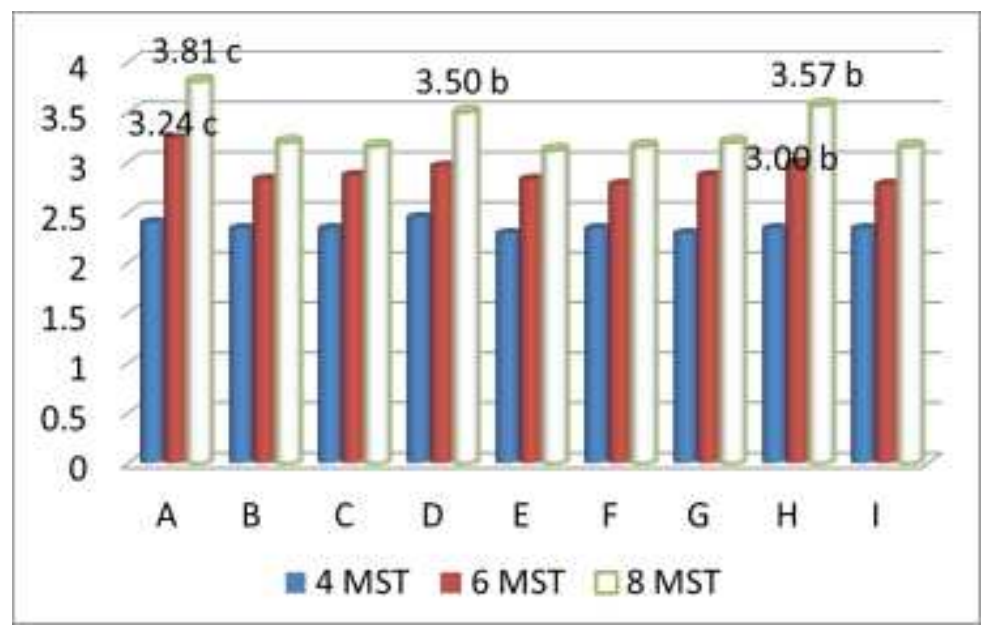

Figure 2. The effect of Macro-micro Fertilizer ratio on number of leaf Brassicaoleracea

\subsection{Leaf Area}

The AB Mix has the best nutrition formulation that is sufficient for plant needs. Beside that, $\mathrm{H}$ treatment gives the second best of the research Then, N, P and K elements have an influence on the leaf area too (Table 1).

Table 1. The effect of Macro-micro Fertilizer ratio on leaf area Brassica oleracea

\begin{tabular}{cc}
\hline Treatment & Leaf area \\
& $--\mathrm{cm} 2--$ \\
\hline A & $17.18 \mathrm{~d}$ \\
B & $7.29 \mathrm{a}$ \\
C & $7.07 \mathrm{a}$ \\
D & $9.44 \mathrm{bc}$ \\
E & $7.67 \mathrm{a}$ \\
F & $7.33 \mathrm{a}$ \\
G & $9.16 \mathrm{~b}$ \\
H & $14.14 \mathrm{c}$ \\
I & $6.50 \mathrm{a}$ \\
\hline
\end{tabular}

Means followed by the same letters in the colums are not different from each other by the Duncan test at $5 \%$

Nutrient supply ( $\mathrm{N}$ equivalent) was higher in Controlled Realise Fertilizer (CFR), the nutrient supply linearly increased with increasing Leaf Area irrespective of fertilizer rate and plant density in each cropping season[9]. $\mathrm{N}$ is a nutrient for vegetative growth, while $\mathrm{P}$ is part of the cell nucleus that will increase cell division in the leaf area, and $\mathrm{K}$ is the activation of a number of free enzymes which are important for photosynthesis and respiration [10]. Beside that, the increasing leaf area increases the leaf area of light reception so that the greater photosynthate and organic matter is produced which is then translocated to other parts[7]. The photosynthate produced will be translocated to the closest part for plant growth and development.

\subsection{Chrophyll}

Besides these elements affect the number of leaves and leaf area, it also affects for amount of plant chlorophyll (Table 2). One of the factors that helps support is environmental factors. 
Where at the research site, the incoming sunlight grew enough to help some plants to make chlorophyll

Table 2. Besides these elements affect the number of leaves and leaf area, it also affects for amount of plant chlorophyll

\begin{tabular}{cc}
\hline Treatment & $\begin{array}{c}\text { Chorophyll } \\
\text {-- unit spad -- }\end{array}$ \\
\hline A & $7,29 \mathrm{e}$ \\
B & $5,60 \mathrm{~b}$ \\
C & $5,38 \mathrm{a}$ \\
D & $5,83 \mathrm{c}$ \\
E & $5,70 \mathrm{bc}$ \\
F & $5,35 \mathrm{a}$ \\
G & $5,60 \mathrm{~b}$ \\
H & $6,93 \mathrm{~d}$ \\
I & $5,35 \mathrm{a}$ \\
\hline
\end{tabular}

Means followed by the same letters in the colums are not different from each other by the Duncan test at $5 \%$

Also, the N element in NPK plays a very important role in the vegetative period and chlorophyll formation because $\mathrm{N}$ is a constituent of all proteins and nucleic acids [8]. Micro elements which is needed in small amounts, are needed for plants too. In its function it forms chlorophyll and helps photosynthesis, the micro elements in micro soluble micro mix that play a role are $\mathrm{Cu}, \mathrm{Mn}$, and $\mathrm{Zn}$ [11]. These three elements are found in micro-soluble mix elements that are used and are soluble in water so they are easily absorbed by plants.

However, in some treatments, there is only a small amount of chlorophyll. This can be due to minimal absorption of root factors in nutrition. The $\mathrm{Ca}$ element which plays a role in the formation of plant cell walls and stimulates the formation of fine roots [12]. However, because of its low solubility, it causes a lack of $\mathrm{Ca}$ intake for plants.

So, we can conclude that the ratio of NPK $(1562,5 \mathrm{~g}): \mathrm{CaSO}_{-} 4(350,12 \mathrm{~g}): \mathrm{MgSO} \_4$ $(730,1)$ : K2SO4 (324,78 g) : Micro soluble micro mix (90 g) was recommended as an alternative to subtitate $\mathrm{AB}$ Mix nutrient. Stock trading is an economic activity that requires high accuracy in its application.

\section{Conclusion}

1. Macro micro fertilizer ration effected on number of leaf, leaf area, and number of chorophyll Brassica olerace

2. The Ratio of NPK fertilizer (1,562.5 g) : $\mathrm{CaSO}_{4}(350,12 \mathrm{~g}): \mathrm{MgSO}_{4}(730,1 \mathrm{~g}): \mathrm{K}_{2} \mathrm{SO}_{4}$ (324,78 g): $90 \mathrm{~g}$ soluble micro mix was recommended as an alternative to subtitute $\mathrm{AB}$ mix nutrient 


\section{Acknowledgments}

We authors thank to Dean and Head of Agrotechnology department for supporting the research

\section{References}

[1] R. Lazar, R. Lacatusu, and N. Rizea, "The influence of water source for preparing the nutrient solutions used for cucumbers irrigation in hydroponic greenhouse," Resarch J. Agric. Sci., vol. 47, no. 3, pp. 97-101, 2015.

[2] A.-C. Fulgencio et al., "An improved, low-cost, hydroponic system for growing Arabidopsis and other plant species under aseptic conditions," BMC Plant Biol., vol. 14, p. 69, 2014.

[3] M. Subandi, N. P. Salam, and B. Frasetya, "Pengaruh Berbagai Nilai Ec ( Electrical Conductivity ) Terhadap Pertumbuhan Dan Hasil Bayam ( Amaranthus Sp .) Pada Hidroponik Sistem Rakit Apung ( Floating Hydroponics System ), J. Agro, vol. IX, no. 2, 2015.

[4] C. Hidayat, B. Frasetya, and I. N. Syamsudin, "Adjustment of phosphorus concentration to increase growth and yield of cherry tomato using hydroponic drip system," J. Agro, vol. 5, no. 2, pp. 140-147, 2018.

[5] T. Jug and B. Slamic, "Lettuce growth in extreme conditions," Emirates J. Food Agric., vol. 28, p. 1, Jun. 2016.

[6] M. R. Shaibur, T. Islam, and S. Kawai, "Response of leafy vegetable Kalmi (water spinach; Ipomoea aquatica L.) at elevated concentrations of arsenic in hydroponic culture," Water. Air. Soil Pollut., vol. 202, no. 1-4, pp. 289-300, 2009.

[7] H. R. E. SOARES, Ê. F. D. F. E. SILVA, G. F. DA SILVA, R. M. DE LIRA, and R. R. BEZERRA, "Mineral Nutrition of Crisphead Lettuce Grown in a Hydroponic System With Brackish Water," Rev. Caatinga, vol. 29, no. 3, pp. 656-664, 2016.

[8] X. Ding et al., "Electrical conductivity of nutrient solution influenced photosynthesis, quality, and antioxidant enzyme activity of pakchoi (Brassica campestris L. Ssp. Chinensis) in a hydroponic system," PLoS One, vol. 13, no. 8, pp. $1-16,2018$.

[9] T. Kinoshita, T. Yano, M. Sugiura, and Y. Nagasaki, "Effects of controlled-release fertilizer on leaf area index and fruit yield in high-density soilless tomato culture using low node-order pinching," PLoS One, vol. 9, no. 11, 2014.

[10] D. S. C. P. CARDOSO, M. A. N. SEDIYAMA, Y. POLTRONIERI, M. C. M. FONSECA, and Y. F. NEVES, "Effect of Concentration and N:K Ratio in Nutrient Solution for Hydroponic Production of Cucumber," Rev. Caatinga, vol. 30, no. 4, pp. 818-824, 2017.

[11] H. Zhang, W. Ding, X. He, H. Yu, J. Fan, and D. Liu, "Influence of 20-year organic and inorganic fertilization on organic carbon accumulation and microbial community structure of aggregates in an intensively cultivated sandy loam soil," PLoS One, vol. 9, no. 3, 2014.

[12] F. Wang, Z. Wang, C. Kou, Z. Ma, and D. Zhao, "Responses of wheat yield, macro- and micro-nutrients, and heavy metals in soil and wheat following the application of manure compost on the North China Plain," PLoS One, vol. 11, no. 1, pp. 1-19, 2016. 